\title{
Implementation of Erp in Business Process Based On Cloud Computing
}

\author{
${ }^{1}$ P. Vimalkumar, ${ }^{2}$ A. Rajamani, ${ }^{3}$ Dr.P.Jayasubramanian \\ ${ }^{1}$ Assistant Professor, Department Of Commerce, Dr. N. G. P. Arts \& Science College, Cbe-48 \\ ${ }^{2}$ Lecturer, Department Of Management Studies Tamilnadu College Of Engineering, Cbe \\ ${ }^{3}$ Head \& Assistant Professor, Department Of Commerce, Dr.N.G.P. Arts \& Science College, Cbe-48
}

\begin{abstract}
Software as service is linked to the concept of cloud computing is a style of computing where information technologies enable business products, services and solutions as a service over the internet. The concept of SAS (Software as Service) is currently in very early stages of development. There are a lot of researchers being carried out in this area. The authors focused to analyze the SAS and also to propose a concept based on qualitative studies for business process integration and industrial collaboration, in the context of small business. The primary aim of this research work is to integrate process not only within the organization but also with the partners and customers.
\end{abstract}

\section{Introduction}

The initials ERP originated as an extension of MRP (material requirements planning; later manufacturing resource planning) and CIM (Computer Integrated Manufacturing). ERP systems now attempt to cover all core functions of an enterprise, regardless of the organization's business or charter. To be considered an ERP system, a software package must provide the function of at least two systems. For example, a software package that provides both payroll and accounting functions could technically be considered an ERP software package. Examples of modules in an ERP which formerly would have been stand-alone applications include: Product lifecycle management, Supply chain management (e.g. Purchasing, Manufacturing and Distribution), Warehouse Management, Customer Relationship Management (CRM), Sales Order Processing, Online Sales, Financials, Human Resources, and Decision Support System.

\section{What is Business Process?}

"A business process is a structured set of business activities designed to deliver a product or service to meet the expectations of the customers and stakeholders involved in the business whether directly or indirectly."

\section{What is ERP?}

"ERP is an integrated system that allows information to enter at a single point in the process (example: at the material-receiving stage of a manufacturing process) and updates a single shared database for all functions that directly or indirectly depends on this information".

\section{What is cloud computing?}

Cloud computing is a general term for anything that involves delivering hosted services over the Internet. These services are broadly divided into three categories: Infrastructure-as-a-Service (IaaS), Platformas-a-Service (PaaS) and Software-as-a-Service (SaaS). The name cloud computing was inspired by the cloud symbol that's often used to represent the Internet in flowcharts and diagrams.

\section{So what about Cloud-based ERP?}

Modern ERP systems are actually made for The Cloud. Personalization features, custom configuration options, customizable screens, personal menus, customizable portals, better ad-hoc reporting and Business Intelligence, flexible end-user data import and export capabilities, and built-in workflow and tools all reduce the need for custom programming, typically done on a traditional on-premise ERP application. Most modern ERP systems are also web-based, running from zero footprint client browsers. Couple this with Security and Internet bandwidth improvements, world-wide connectivity and availability and the stage has been set. Cloud-based ERP systems are not somewhere in the future. They are here today. 


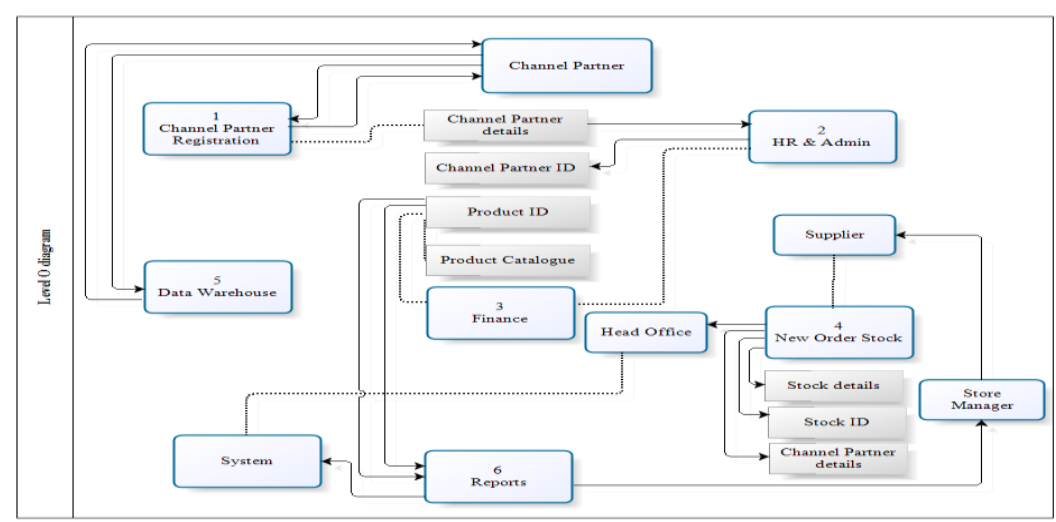

\section{System Requirements}

\section{Functional Requirements:}

It describes what the system, process, or product/service must do in order to fulfil the business requirements. A business requirement often can be broken up into sub-business requirements and many functional requirements. These are often referred to as System Requirements although some functionality could be manual and not system based. Functional requirements may be calculations, technical details, data manipulation and processing and other specific functionality that define what a system is supposed to accomplish.

\section{User Requirements:}

These are a very important part of the deliverables; the needs of the stakeholders will have to be correctly interpreted. This deliverable can also reflect how the product will be designed, developed, and define how test cases must be formulated.

\section{Non Functional Requirements :}

Functional requirements are supported by non-functional requirements (also known as quality requirements), which impose constraints on the design or implementation (such as performance requirements, security, or reliability). For example: performance, scalability, reliability, robustness, quality of service (QoS), security and usability. Requirement analysis is critical to the success of a development project. Requirements must be actionable, measurable, testable, related to identified business needs or opportunities, and defined to a level of detail sufficient for system design.

\section{System Analysis}

To understand the concept and the figure out the answers for the following questions pertaining to ERP implementation.

- How can ERP improve a company's business performance?

- How long will an ERP project take?

- What will ERP fix in a business?

- What does ERP really cost?

- Who are the major market players today?

- What are the limitations of ERP

How can ERP improve a company's business performance especially in a manufacturing firm?

ERP automates the tasks involved in performing a business process - such as order fulfillment, which involves taking an order from a customer, shipping it and billing for it (the customer's credit rating and order history, the company's inventory levels and the shipping dock's trucking schedule).

\section{How long will an ERP project take?}

For the successful installation of ERP, the business flows might have to undergo changes, and the ways people do their jobs will need to change too. And that kind of change is time consuming. The important thing is not to focus on how long it will take - real transformational ERP efforts usually run between one to three years, on average - but the challenge is to accurately figure out why ERP is required for that organization and how to utilize it to reap the harvest out of it. 
What will ERP fix in a business?

There are three major reasons why companies undertake ERP:

- To standardize manufacturing processes:

- To standardize HR information. :

- To integrate financial data.

What does ERP really cost?

Total Cost of Ownership (TCO) of ERP; include cost for hardware, software, professional services, and internal staff costs. The TCO numbers include getting the software installed and the two years afterward, which is when the real costs of maintaining, upgrading and optimizing the system for business are felt.

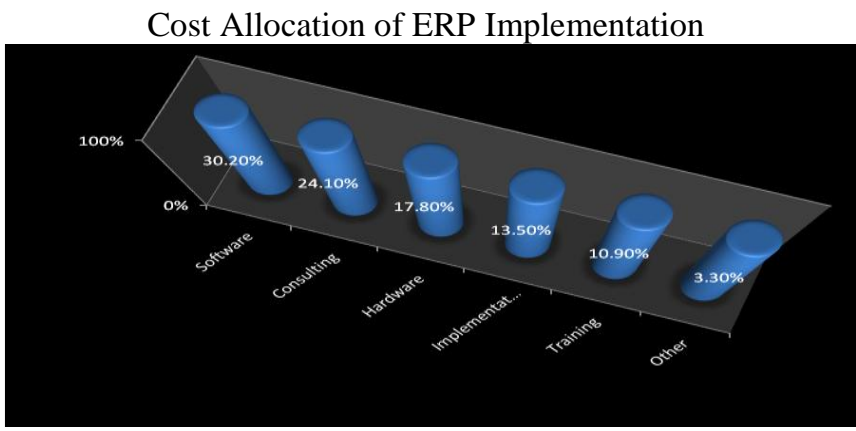

IV. System Design

The blueprint shows how the various processes interchange information with each other as well as with the underlying data model.The company is mainly concentrated on the channel partners they are the backbone of the company, because the products reach to the valuable customers.

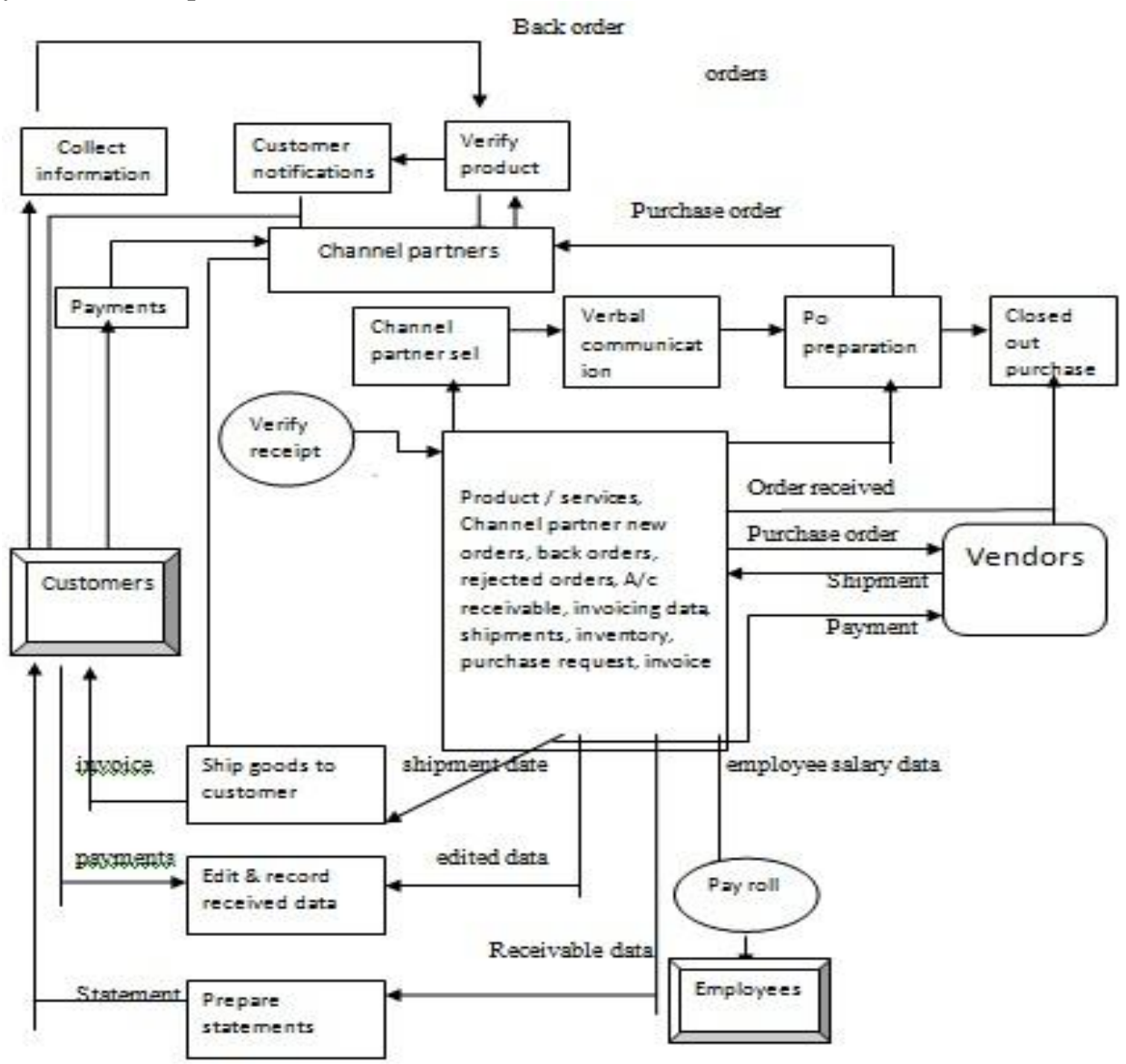


Implementation Of Erp In Business Process Based On Cloud Computing

\begin{tabular}{|c|c|c|c|c|c|}
\hline EVENT & TRIGGER & SOURCE & USAGE & RESPONSE & $\begin{array}{l}\text { DESTINATI } \\
\text { ON }\end{array}$ \\
\hline $\begin{array}{l}\text { Channel } \\
\text { partner } \\
\text { registratio } \\
n\end{array}$ & $\begin{array}{l}\text { Channel partner } \\
\text { registering }\end{array}$ & $\begin{array}{l}\text { Channel } \\
\text { partner }\end{array}$ & $\begin{array}{l}\text { Giving the all } \\
\text { information } \\
\text { about the } \\
\text { channel partner }\end{array}$ & Membership & $\begin{array}{l}\text { Channel } \\
\text { partner }\end{array}$ \\
\hline $\begin{array}{l}\text { Automatic } \\
\text { email } \\
\text { generation }\end{array}$ & $\begin{array}{l}\text { Automatic due } \\
\text { list }\end{array}$ & System & $\begin{array}{l}\text { Select the } \\
\text { channel partner }\end{array}$ & $\begin{array}{l}\text { Generate the } \\
\text { email }\end{array}$ & $\begin{array}{l}\text { Channel } \\
\text { partner }\end{array}$ \\
\hline Inventory & $\begin{array}{l}\text { Recording new } \\
\text { stock }\end{array}$ & System & $\begin{array}{l}\text { Storing the } \\
\text { goods }\end{array}$ & Stock storage & $\begin{array}{l}\text { Store } \\
\text { manager }\end{array}$ \\
\hline Product id & Product details & $\begin{array}{l}\text { Head } \\
\text { office }\end{array}$ & $\begin{array}{l}\text { Category the } \\
\text { product }\end{array}$ & $\begin{array}{l}\text { Creating } \\
\text { product list }\end{array}$ & Head office \\
\hline $\begin{array}{l}\text { New stock } \\
\text { receiving }\end{array}$ & Recorded send & Supplier & $\begin{array}{l}\text { Categories the } \\
\text { stock }\end{array}$ & $\begin{array}{l}\text { Stock } \\
\text { received }\end{array}$ & Head office \\
\hline $\begin{array}{l}\text { Processing } \\
\text { of received } \\
\text { stock }\end{array}$ & $\begin{array}{l}\text { Receive the } \\
\text { stocks }\end{array}$ & $\begin{array}{l}\text { Head } \\
\text { office }\end{array}$ & Hold the stock & $\begin{array}{l}\text { Entering the } \\
\text { product } \\
\text { details }\end{array}$ & Store \\
\hline $\begin{array}{l}\text { Generate } \\
\text { purchase } \\
\text { order }\end{array}$ & $\begin{array}{l}\text { Creating order } \\
\text { list }\end{array}$ & $\begin{array}{l}\text { Store } \\
\text { manager }\end{array}$ & $\begin{array}{l}\text { Checking the } \\
\text { order list }\end{array}$ & $\begin{array}{l}\text { Sent to the } \\
\text { supplier }\end{array}$ & Supplier \\
\hline $\begin{array}{l}\text { Catalogue } \\
\text { of product }\end{array}$ & $\begin{array}{l}\text { Preparing } \\
\text { product } \\
\text { catalogue }\end{array}$ & System & $\begin{array}{l}\text { Get the } \\
\text { available data }\end{array}$ & $\begin{array}{l}\text { Preparing } \\
\text { report }\end{array}$ & $\begin{array}{l}\text { Store } \\
\text { manager }\end{array}$ \\
\hline $\begin{array}{l}\text { General } \\
\text { ledger }\end{array}$ & $\begin{array}{l}\text { Accounting } \\
\text { details }\end{array}$ & System & Over all entries & $\begin{array}{l}\text { Audit the } \\
\text { details }\end{array}$ & $\begin{array}{l}\text { Accounts } \\
\text { manager }\end{array}$ \\
\hline $\begin{array}{l}\text { Human } \\
\text { resource }\end{array}$ & $\begin{array}{l}\text { Administration } \\
\text { details }\end{array}$ & System & $\begin{array}{l}\text { Selecting the } \\
\text { right candidate } \\
\text { for right job }\end{array}$ & $\begin{array}{l}\text { Recruit and } \\
\text { selection } \\
\text { process }\end{array}$ & Hr manager \\
\hline Payroll & $\begin{array}{l}\text { Employee } \\
\text { salary details }\end{array}$ & System & $\begin{array}{l}\text { Employee } \\
\text { performance }\end{array}$ & Evaluation & Hr manager \\
\hline
\end{tabular}

\section{System Testing}

Software Testing is an empirical investigation conducted to provide stakeholders with information about the quality of the product or service under test, with respect to the context in which it is intended to operate. Testing can never completely identify all the defects within software. Instead, it furnishes a criticism or comparison that compares the state and behaviour of the product against oracles - principles or mechanisms by which someone might recognize a problem.

\section{Functional Testing}

In this type of testing, the software is tested for the functional requirements. Functional testing covers how well the system executes the functions it is supposed to execute - including user commands, data manipulation, searches and business processes, user screens, and integrations. Functional testing covers the obvious surface type of functions, as well as the back-end operations (such as security and how upgrades affect the system).

\section{Non Functional Testing}

This testing ensures that the system / software guarantee a high level of performance. Different types include:

- Compatibility testing - Compatibility testing ensures that the software is compatible with the hardware, operating systems, and other software packages that it will be working with.

- Performance testing - Performance testing determines how well the software performs in terms of the speed of computations or responsiveness to the user.

- Scalability testing - Scalability testing is performed to ensure that the software will function well as the number of users, size of data sets, or other factors change from small to large values.

- Usability testing - Usability testing ensures that the software has a good level of ease of use.

- Application security testing - Application security testing determines how well the software can defend against attacks, such as firewall software securing a computer against Internet viruses and worms. 
- Accessibility testing - Accessibility testing is performed to ensure that the software will be accessible under various scenarios by the intended users.

- Regulatory-compliance testing - Regulatory-compliance testing is performed to ensure that the software is in compliance with all applicable regulations.

\section{Test Case}

A test case in software engineering is a set of conditions or variables under which a tester will determine whether an application or software system is working correctly or not. Test cases are often referred to as test scripts, particularly when written. Test cases can be either formal or informal test cases.

\section{Getting Ready For Erp Implementation}

An organization needs to answer the following questions while thinking of taking up ERP.

- Perception of the business problems

- The visualization of solving them.

- How is ERP going to solve the same and how worth is it and how effective are the measures taken to implement it.

- How and who will coordinate the operation of ERP and is it justified in terms of costs, time taken and efforts.

\section{ERP Implementation Life Cycle}

The process of ERP implementation is referred as d as "ERP Implementation Life Cycle". The following are the steps involved in completing the lifecycle.

\section{Shortlist On The Basis Of Observation}

Selecting an ERP package for the company can nevertheless be compared with the process of "Selecting the right Person for the Right Job". This exercise will involve choosing few applications suitable for the company from the whole many.

\section{Assessing The Chosen Packages}

A team of Experts with specialized knowledge in their respective field will be asked to make the study on the basis of various parameters. Each expert will not only test and certify if the package is apt for the range of application in their field but also confirm the level of coordination that the software will help to achieve in working with other departments. In simple terms they will verify if the synergy of the various departments due to the advent of ERP will lead to an increased output.

\section{Preparing For The Venture}

This stage is aimed at defining the implementation of ERP in all measures. It will lay down the stipulations and criteria to be met. A team of officers will take care of this, who will report to the person of the highest hierarchy in the organization.

\section{Gap Analysis}

This stage helps the company to identify the gaps that has to be bridged, so that the company practice becomes akin to ERP environment. This has been reported as an expensive procedure but it is inevitable.

\section{Business Process Reengineering}

Changes in employee rolls, business process and technical details find place in this phase of restructuring most popularly referred as business process engineering.

\section{Designing The System}

This step requires lot of meticulous planning and deliberate action. This step helps to decide and conclude the areas where restructuring have to be carried on. A choice is to be made from ERP implementation models.

\section{Checking}

This stage observes and tests the authenticity of the use. The system is subjected to the wildest tests possible so that it ensures proper usage and justifies the costs incurred. This is seen as a test for ERP implementation 


\title{
Preparing the Employees To Use ERP
}

The employees in the organization will be taught to make use of the system in the day to day and regular basis so as to make sure that it becomes a part of the system in the organization.

\section{Post Implementation}

The process of implementation will find meaning only when there is regular follow up and proper instruction flow thereafter and through the lifetime of ERP. This will include all efforts and steps taken to update and attain better benefits once the system is implemented. Hence an organization has to perform ERP implementation safely and correctly.

\section{ISSUES}

Some more issues that arise during and after the course of ERP implementation is discussed below:

\section{Enhancement Of Erp's Functions}

Erg's scope gets wider as it is implemented in an organization. There is a call for including many tasks under the purview. This dilutes the ERP Existing system after modifying it a couple of times. Repeated change in configurations and systems will only add to the confusions.

When the functions are operated by a machine it becomes increasingly difficult to make the necessary changes. These troubles arise when they are not foreseen and addressed in the implementation stage. They have to be given a place in ERP implementation plan.

\section{Organizational Reaction To Changes}

Changes do happen quickly and immediately in the organization after ERP is implemented. But if there is no proper understanding of the process or mishandling of information, it will result in questioning the ERP process. If updating is not done in the machine it will only affect the business process and create unnecessary confusions. If that happens the chances of ERP implementation success are great.

\section{Inflating Resources For Erp Implementation}

The implementation time and money always exceeds the promises and stipulated deadline and amount. This makes companies to lose faith on ERP and ERP vendors. They think that ERP vendors overplay on the costs and time required but it is not so. They don't disclose it in the beginning because it would look like exaggerating. In fact no one would like to lose a prospective business and vendors are equally aware of the fact that "Truths are always bitter"!

\section{Organizations Non Adherence To The Stated Principles}

Organizations largely experience a wide gap between practices and preaching .In fact this has a negative effect on the entire business scenario itself. The voracity and impact of loss could be greater and more devastating when this turns out to be true even in the case of ERP.

\section{Conclusion}

Cloud computing provides companies with new options for managing infrastructures and new business models. In particular, it can mean a big improvement for small and medium-size companies, for whom the cloud represents the opportunity to reduce costs in administration and in maintaining proprietary infrastructures, providing them with technological possibilities similar to those of large companies. The future of Cloud ERP is going to be an exciting one. People will be transitioning technologies and as a result, many legacy systems will likely be retired Only those providers with the most up to date technologies will be able to survive, because Cloud updates happen so fast and so regular. Imagine having pushed updates every quarter that just appear. The next five years should be very exciting as more and more providers and customer's transition to Cloud ERP.

\section{Books}

\section{Bibliography}

[1] Enterprise Resource Planning, Tata McGraw Hill Education Private Limited, Second Edition by Alexis Leon

[2] Enterprise Resource Planning, Macmillan India Limited by Mahadeo Jaiswal \& Ganesh Vanapalli

\section{WEBSITES}

\author{
[3] www.wikipedia.org \\ [4] www.lighttapeindia.com \\ [5] http://www.erppandit.com/erp-implementation.html \\ [6] http://www.visibility.com/
}

